\title{
THE USE OF HEMOLYSIN INHIBITION IN THE STUDY OF EXPERIMENTAL AND CLINICAL HYPERLIPEMIA: THE NON-SPECIFIC INHIBITION OF STREPTOLYSIN O BY SERUM LIPOPROTEINS ${ }^{1}$
}

\author{
BY GENE H. STOLLERMAN WITH THE TECHNICAL ASSISTANCE OF LUCILLE BRALOWER \\ AND KENJI NOGAKI \\ (From Irvington House and the Department of Medicine, New York University College of \\ Medicine, $N . Y$.)
}

(Submitted for publication March 8, 1954 ; accepted May 20, 1954)

Streptolysin $O$ is one of a group of hemolytic toxins that have in common the property of being inhibited by cholesterol. This property is also shared by saponin, a hemolytic agent of quite a different type. Other hemolytic toxins, such as streptolysin $\mathrm{S}$, are not inhibited by cholesterol but are neutralized by phospholipids (1-3).

Certain observations suggest that the inhibition of these hemolysins by serum is influenced by the physicochemical state of serum lipoproteins. For example, the cholesterol contained in normal human and animal sera does not inhibit streptolysin $O$ hemolysis. Old samples of sera, or sera contaminated by certain strains of bacteria, do become strongly inhibitory, however (2). Under these conditions the serum cholesterol is presumably liberated from lipoprotein complexes. Streptoly$\sin \mathrm{S}$ has been shown to be inhibited by serum lipoproteins. This inhibition may be varied by measures which alter the native state of these proteins or by diseases which are associated with disturbances in lipid metabolism (4-8). Also, the inhibition of saponin hemolysis by whole plasma is not a simple function of the concentration of its lipid components. The sum of the inhibition produced by each of the lipid and protein components of plasma is not as great as the inhibition of saponin hemolysis by whole plasma (9).

These and other observations suggest that further study of hemolysin inhibition by sera of abnormal lipid composition may detect changes in lipoproteins in intact serum which may not be readily revealed by conventional analytical methods. This report describes the inhibition of two cholesterol sensitive hemolysins, streptolysin $O$

1 This study was supported in part by a grant from the Masonic Foundation for Medical Research and Human Welfare. and saponin, by the sera of patients with disturbances of lipid metabolism.

\section{MATERIALS AND METHODS}

Preservation of sera: Sera obtained from patients and from animals were stored at $-20^{\circ} \mathrm{C}$. Determinations of inhibition of streptolysin $O$ were carried out before freezing the serum, and within 48 hours after blood had been drawn. It was observed that freezing and thawing of samples resulted, in some instances, in significant loss of inhibition or in bizarre "prozone" reactions.

Titrations and chemical determinations: Titration of streptolysin $O$ inhibition (SOI) was performed by the following method suggested by Dr. Alan W. Bernheimer: Dilutions of serum and of streptolysin $O$ were made in saline-phosphate buffer at $\mathrm{pH} 7.0(\mathrm{M} / 15$ phosphate and M/12.9 sodium chloride). Sera were heated for $30 \mathrm{~min}$ utes at $56^{\circ} \mathrm{C}$. and two-fold serial dilutions were prepared in volumes of $0.5 \mathrm{ml}$. per tube. When more exact titration was required, closer dilution increments of 0.1 in the logarithm of the dilution factor were employed. A partially purified and concentrated preparation of streptolysin $\mathrm{O}$ containing 8,000 hemolytic units per $\mathrm{ml}$. was used in these studies.2 (A hemolytic unit is defined as the amount of streptolysin $\mathrm{O}$ in one $\mathrm{ml}$. of salinephosphate buffer which produces $\mathbf{5 0}$ per cent hemolysis of $1 \mathrm{ml}$. of a 0.7 per cent suspension of washed, human erythrocytes in 30 minutes at $37^{\circ} \mathrm{C}$.) One ml. of a $1: 5$ dilution of the preparation of streptolysin 0 employed was reduced by the addition of one $\mathrm{ml}$. of a 1 per cent solution of cysteine brought to $\mathrm{pH} 7$ by the addition of 1 normal sodium hydroxide with bromthymol blue as indicator. The streptolysin O-cysteine solution was held for $10 \mathrm{~min}$ utes at $20^{\circ} \mathrm{C}$. to allow complete reduction of the hemoly$\sin$ to take place. The solution of streptolysin $O$ was further diluted to a final concentration of $1: 250$ in salinephosphate buffer to obtain a final dilution containing 32 hemolytic units per ml. of active, reduced streptolysin 0 . This solution was promptly added in a volume of $0.5 \mathrm{ml}$. to each tube containing $0.5 \mathrm{ml}$. of serum dilution and the mixture incubated at $20^{\circ} \mathrm{C}$. for 10 minutes. One ml. of a 0.7 per cent suspension of washed, human erythrocytes was added to each tube and the tubes were incubated for

\footnotetext{
${ }^{2}$ Kindly supplied by Dr. Alan W. Bernheimer.
} 
30 minutes at $37^{\circ} \mathrm{C}$. After this incubation the tubes were centrifuged for five minutes at 1,500 R.P.M. in a No. 2 International centrifuge and the degree of hemolysis in the supernate of each tube was noted. The endpoint was considered the highest dilution of serum causing complete inhibition of hemolysis. With each group of unknown sera, a standard serum of known titer was run as a control. The number of units of streptolysin $\mathrm{O}$ inhibition per $\mathrm{ml}$. of serum was expressed as the reciprocal of the quantity of serum producing complete inhibition of hemolysis. The unitage thus expressed is approximately similar to the combining unit of Todd (10) employed for the measurement of antistreptolysin $\mathrm{O}$ antibody.

Antistreptolysin $O$ determinations for the measurement of specific serum antibody (in distinction to the above measurement of non-specific streptolysin $O$ inhibition by lipids) were performed by the method of Todd (10) as modified by Rantz and Randall (11).

Saponin inhibition was measured by a method identical to that described above for streptolysin $O$ inhibition, substituting for streptolysin $\mathrm{O}$ a 10 per cent aqueous solution of saponin diluted 1:80 in saline-phospate buffer. This solution contained 16 hemolytic units per $0.5 \mathrm{ml}$. Streptolysin $S$ inhibition was determined by the method of Stollerman and Bernheimer (6).

Serum cholesterol concentration was determined by the method of Schoenheimer and Sperry (12) as modified by Sperry and Webb (13). Serum phospholipid concentration was measured by the method of Zilversmit and Davis (14). Lipid was removed from serum at low temperatures with ether-alcohol mixtures as described by MacLeod and Avery (15).

Absorption of specific antibody against streptolysin $O$ : to differentiate specific from non-specific inhibition of streptolysin $O$ by human sera, antistreptolysin $O$ antibody was absorbed by incubating equal parts of serum and streptolysin $\mathrm{O}$ solution, containing an excess of the hemolysin, for 15 minutes at $37^{\circ} \mathrm{C}$. The residual, unneutralized streptolysin $\mathrm{O}$ was then destroyed by heating the mixture at $56^{\circ} \mathrm{C}$. for one hour.

Digestion of serum phospholipid by lecithinase: The lecithinase employed was the alpha toxin of Clostridium welchii, partially purified according to the method of Adams and Hendee (16). The lot employed contained $250 \mathrm{MLD}$ for mice per $\mathrm{ml}$. and $8 \mathrm{Lb}$ units (antitoxin binding power). Digestion of serum lecithin was carried out as described by Stollerman, Bernheimer, and MacLeod (4).

\section{Methods for inducing hyperlipemia in rabbits}

Cholesterol feeding: Six rabbits weighing 1.5 to 3.0 $\mathrm{Kg}$. consumed an average of $34 \mathrm{Gm}$. of cholesterol per week. Purina rabbit pellets were coated with cholesterol by soaking them in ether in which cholesterol had been dissolved and then allowing the ether to evaporate. Rabbits were bled from an ear vein at appropriate intervals.

Heparin was administered to a group of six rabbits which were also fed cholesterol as described above. Intravenous injections were made three times weekly of 2.5 ml. of a solution containing $10 \mathrm{mg}$. of heparin per $\mathrm{ml}$. (Lederle's aqueous heparin) during the period of cholesterol feeding.

Triton $W R-1339,3$ a non-ionic detergent, was administered intravenously three times weekly to a group of six rabbits in doses of $1.25 \mathrm{ml}$. per $\mathrm{Kg}$. of a 12.5 per cent aqueous solution (17). While receiving Triton the animals were fed a diet of regular Purina rabbit pellets without added cholesterol.

Alloxan diabetes was induced in four rabbits by minor modifications of the method employed by Pierce (18). Four weeks after permanent diabetes had been established, cholesterol was fed as described above. Several rabbits which developed transient acute hyperlipemia within a few days of receiving an injection of alloxan were bled at frequent intervals until the hyperlipemia cleared or the animal died of alloxan toxicity. The development of diabetes was observed by repeated determinations of blood sugar concentrations.

\section{RESULTS}

\section{Hemolysin inhibition by hyperlipemic rabbit sera}

Cholesterol-fed rabbits: Determinations of titers of streptolysin O inhibition (SOI), streptolysin S

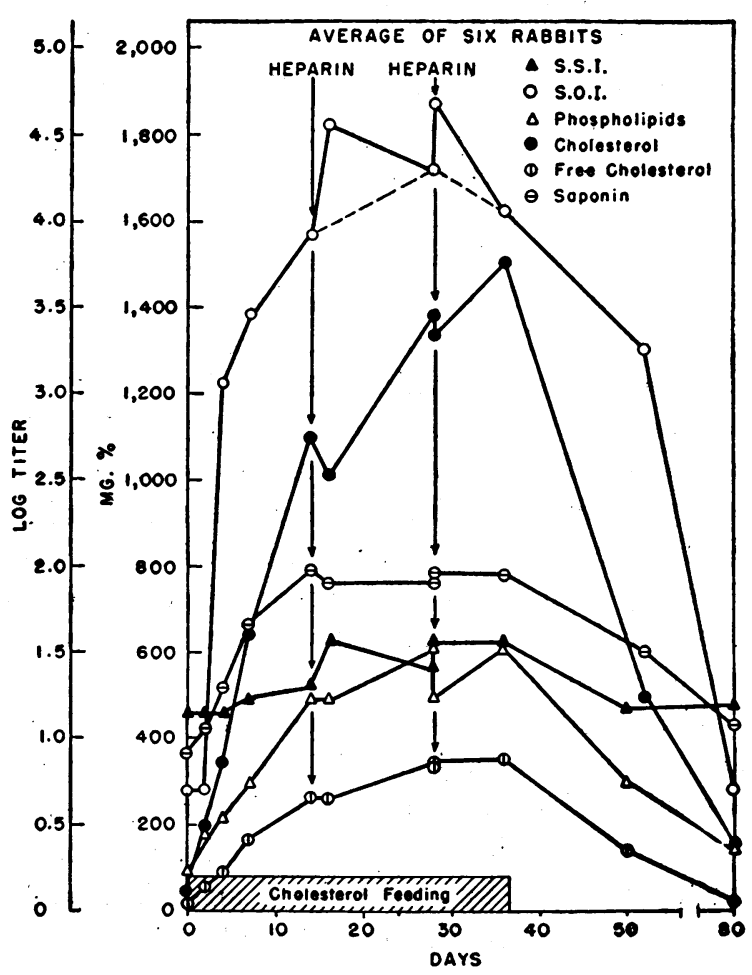

Fig. 1. Effect of Cholesterol Feeding upon Streptolysin O, Streptolysin S ANd Saponin INHIBItion by THE SERA OF RABbits

${ }^{3}$ Kindly supplied by Rohm and Haas. 


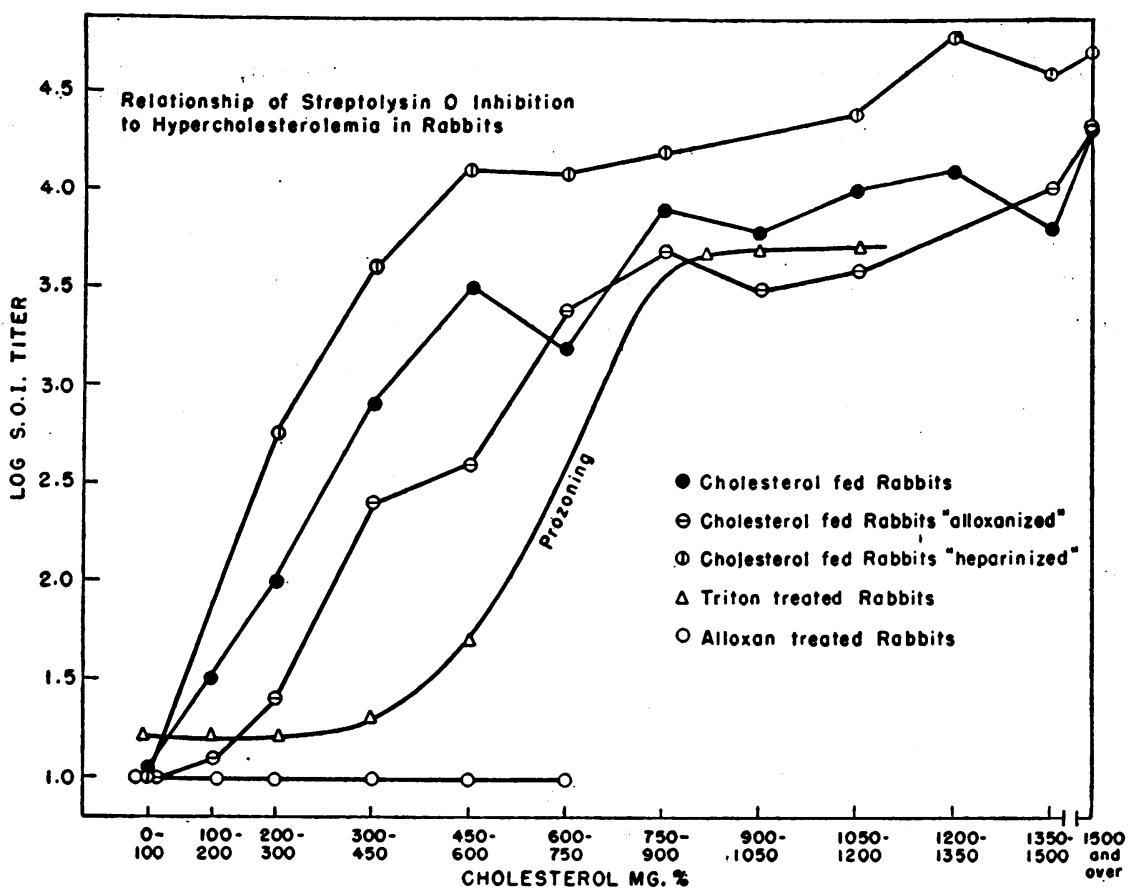

Fig. 2. Relationship of Streptolysin O Inhibition to Various Types of EXPERIMENTAL HyPERCHOLESTEROLEMIA IN RABBITS

inhibition (SSI) saponin inhibition, total and free cholesterol and total phospholipid levels were made on sera obtained from serial bleedings of rabbits fed cholesterol. When the total cholesterol concentration in serum approached levels of approximately $250 \mathrm{mg}$. per cent, there was an abrupt and striking rise in SOI. Streptolysin O inhibition increased to levels of over 10,000 units per $\mathrm{ml}$. and in some animals to 100,000 units per $\mathrm{ml}$. There was also a rise in saponin inhibition titer but of a much smaller magnitude. Streptolysin S inhibition increased two to four fold (Figure 1).

The marked streptolysin $O$ inhibition disappeared completely when serum lipids were extracted at low temperatures with alcohol-ether mixtures. In contrast, the streptolysin $\mathrm{O}$ inhibition was unaffected by absorption of the serum with streptolysin O. This clearly differentiated the inhibition due to lipids from that due to specific antibody. The contrasting effect of these two procedures upon sera of cholesterol-fed rabbits and sera of patients with high titers of specific antistreptolysin $\mathrm{O}$ antibody is demonstrated by the data in Table I.

Effect of intravenous injection of heparin: Be- cause of reports of alterations in the physical state of serum lipids following intravenous injection of heparin (19) the effect of heparin upon inhibition of streptolysin $\mathrm{O}$ was studied. Hypercholesterolemic, cholesterol-fed rabbits, bled three hours after an intravenous injection of $10 \mathrm{mg}$. of heparin, showed a two to four-fold rise in the titer of SOI. This occurred in the absence of significant changes in serum concentration of total or free cholesterol or of phospholipid (Figure 1).

TABLE I

Differentiation of non-specific inhibition of streptolysin $O$ by serum lipoproteins from inhibition due to specific antibody

\begin{tabular}{|c|c|c|c|}
\hline \multirow{2}{*}{$\begin{array}{l}\text { Hypercholes- } \\
\text { teremic } \\
\text { rabbits }\end{array}$} & \multicolumn{3}{|c|}{$\begin{array}{l}\text { Streptolysin "O" inhibition, } u / c c . \\
\text { (non-specific inhibition) }\end{array}$} \\
\hline & $\begin{array}{l}\text { Whole } \\
\text { serum }\end{array}$ & $\begin{array}{l}\text { "Defatted" } \\
\text { serum }\end{array}$ & $\begin{array}{l}\text { Absorbed* } \\
\text { serum }\end{array}$ \\
\hline $\begin{array}{l}\text { No. } 60 \\
\text { No. } 80\end{array}$ & $\begin{array}{r}6,400 \\
19,200\end{array}$ & $\begin{array}{l}<10 \\
<10\end{array}$ & $\begin{array}{r}6,400 \\
19,200\end{array}$ \\
\hline \multirow{2}{*}{$\begin{array}{c}\text { Rheumatic } \\
\text { fever } \\
\text { patients }\end{array}$} & \multicolumn{3}{|c|}{$\begin{array}{c}\text { Antistreptolysin "O" titer, } u / c c \text {. } \\
\text { (specific inhibition) }\end{array}$} \\
\hline & $\begin{array}{l}\text { Whole } \\
\text { serum }\end{array}$ & $\begin{array}{l}\text { "Defatted" } \\
\text { serum }\end{array}$ & $\begin{array}{c}\text { Absorbed* } \\
\text { serum }\end{array}$ \\
\hline $\begin{array}{l}\text { M.G. } \\
\text { J. K. }\end{array}$ & $\begin{array}{l}333 \\
333\end{array}$ & $\begin{array}{l}250 \\
250\end{array}$ & $\begin{array}{l}<50 \\
<50\end{array}$ \\
\hline
\end{tabular}

* Absorbed with streptolysin 0 . 
Determinations of SOI made on the sera of an additional group of six rabbits fed cholesterol and receiving intravenous injections of heparin three times weekly showed consistently higher SOI values at comparable serum concentrations of cholesterol than were observed in the sera of rabbits fed cholesterol alone (Figure 2). This enhancement of SOI could not be demonstrated when heparin was added to these hypercholesterolemic sera in vitro nor was heparin itself found to be inhibitory.

Effect of administration of alloxan: The transient hyperlipemia which occurs in some animals shortly after administration of alloxan $(20,21)$ was studied. In contrast to the sera of cholesterolfed rabbits, the hyperlipemic sera of animals acutely toxic from alloxan failed to inhibit streptolysin $\mathrm{O}$ even at a serum cholesterol concentration of 675 mg. per cent. Rabbits which survived alloxan injection and remained diabetic were observed until the transient hypercholesterolemia had cleared (usually about two to three weeks after injection). The rise in serum cholesterol which occurred was now associated with a marked rise in streptolysin $O$ inhibition, comparable to that observed in normal rabbits fed cholesterol (Figure 2).

Effect of intravenous injection of Triton $W R$ 1339: Rabbits which were repeatedly injected intravenously with the non-ionic detergent Triton WR 1339 became progressively hyperlipemic as described by Kellner, Correll, and Ladd (17).
The sera of these animals did not inhibit streptolysin $O$ hemolysis until cholesterol concentrations approached a level of approximately 400 to 600 mg. per cent. At these levels a "prozone" effect was noted in which complete inhibition of the hemolysin occurred only at high dilutions of serum. This "prozone" tended to disappear when maximal concentrations of serum cholesterol were reached but could not be completely abolished (Table II and Figure 2).

The prozone effect could not be explained by the formation of a new hemolysin resulting from injection of Triton since incubation of red blood cell suspensions with varying dilutions of serum from Triton-treated animals did not reveal hemolytic activity. The possibility was also considered that incubation of streptolysin $\mathrm{O}$ with the serum of Triton-treated rabbits might have resulted in the production of an additional hemolytic substance. This possibility was excluded by experiments wherein streptolysin $O$ was incubated with such sera. After neutralizing excess streptolysin $\mathrm{O}$ by the addition of its specific antibody, the mixture was tested and no hemolytic activity was found. Triton WR 1339 when added to these sera in vitro was not hemolytic in concentrations of less than 12.5 per cent. It is unlikely, therefore, that the prozone could be explained by the presence in serum of Triton per se. Injections of heparin failed to abolish the prozone phenomenon. The mechanism whereby low serum di-

TABLE II

Inhibition of streptolysin $O$ hemolysis by sera obtained during administration of Triton WR 1339, three times weekly, intravenously

\begin{tabular}{|c|c|c|c|c|c|c|}
\hline \multirow[b]{2}{*}{$\begin{array}{l}\text { Serum } \\
\text { dilutions }\end{array}$} & \multicolumn{6}{|c|}{$\begin{array}{c}\text { Rabbit No. } 78 \\
\text { Hemolysis imhibition and concentrations of cholesteral and phospholipid, ms. \%. } \\
\text { in serwm obleined on the dates indicated }\end{array}$} \\
\hline & ${ }_{33}{ }^{2 / 22}{ }_{79}$ & $\underset{268}{\stackrel{9}{9 / 25}}{ }_{500}^{\text {Phos. }}$ & $\begin{array}{c}\text { 10/16 } \\
\text { Chol. Phos. } \\
494\end{array}$ & \begin{tabular}{l}
\multicolumn{2}{c}{$\begin{array}{c}10 / 30 \\
\text { Chal. }\end{array}$ Phos. $^{\text {Ph7 }}{ }_{1452}$}
\end{tabular} & \begin{tabular}{c}
\multicolumn{2}{c}{$11 / 13$} \\
Chol. \\
938
\end{tabular}$\quad \begin{array}{l}\text { Phos. } \\
1932\end{array}$ & 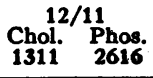 \\
\hline $\begin{array}{r}1 / 10 \\
1 / 20 \\
1 / 40 \\
1 / 80 \\
1 / 160 \\
1 / 320 \\
1 / 640 \\
1 / 1280 \\
1 / 2560 \\
1 / 5120 \\
1 / 10,240 \\
1 / 20,480 \\
1 / 40,960\end{array}$ & 1 & & & $\begin{array}{c}++ \\
++ \\
+ \\
\pm \\
= \\
- \\
- \\
- \\
= \\
\pm \\
+\end{array}$ & $\begin{array}{l}+ \\
\pm \\
\pm \\
- \\
- \\
- \\
- \\
- \\
\pm \\
+ \\
++\end{array}$ & $\begin{array}{c} \pm \\
- \\
- \\
- \\
\overline{ \pm} \\
\pm \\
\pm \\
++\end{array}$ \\
\hline
\end{tabular}

- Complete hemolysis ++++ ; no hemolysis - 


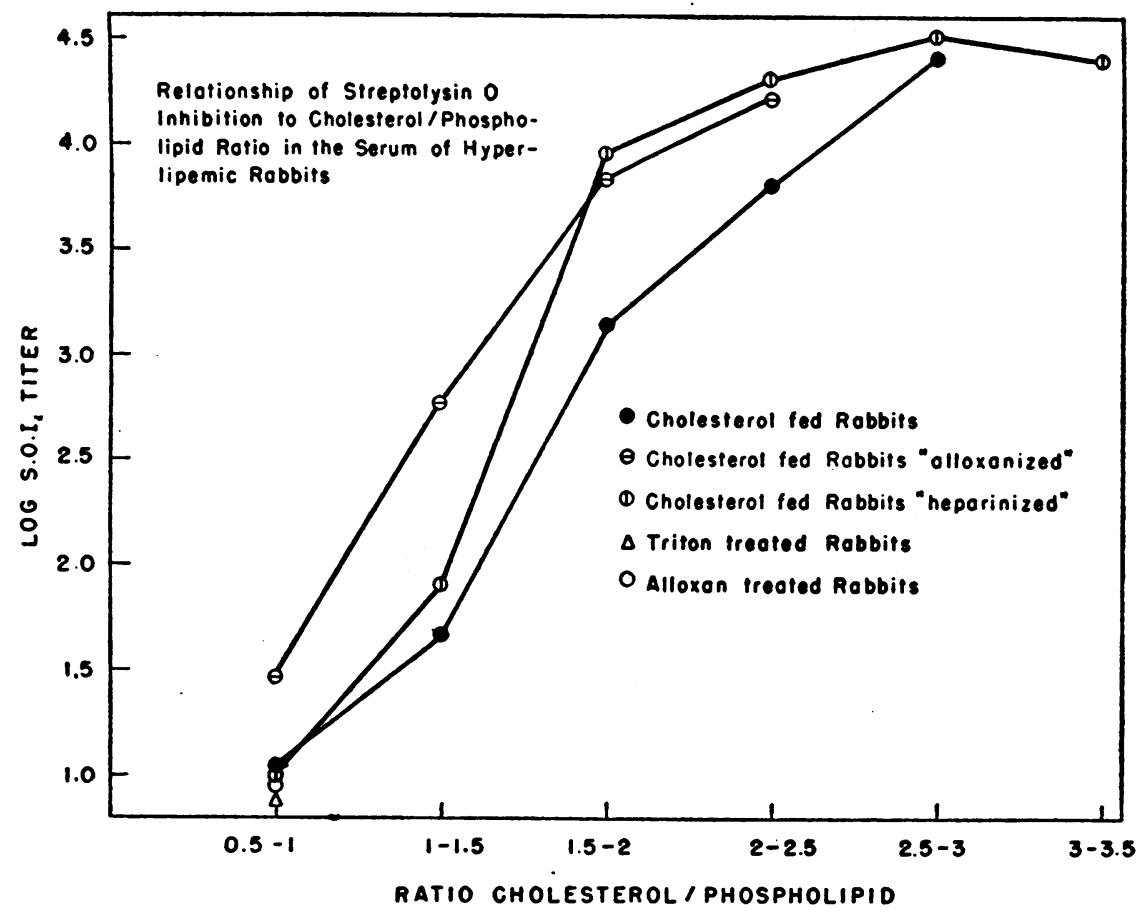

Fig. 3. Relationship of Streptolysin O Inhibition to Cholesterol/PhosphoLIPID Ratio In the SERUM of HyperLIPEMIC RabBits

lutions of this type of hyperlipemic serum fail to inhibit streptolysin $O$ whereas inhibition is apparent at high dilutions was not explained.

The relationship of streptolysin $O$ inhibition to cholesterol phospholipid ratios in the sera of hyperlipemic rabbits: An attempt was made to relate the differences observed in the SOI of various types of hyperlipemic rabbit sera to the ratio of cholesterol phospholipid concentration. The sera of normal rabbits fed cholesterol, and those which received heparin intravenously while being fed cholesterol, showed strong streptolysin $O$ inhibition when the cholesterol/phospholipid ratio in serum approached 1.5. Rabbits made diabetic with alloxan and fed cholesterol showed a prompt rise in SOI titer when this ratio approached 1.0 and increased as the ratio increased (Figure 3 ).

The hyperlipemic sera obtained from rabbits during the stage of acute alloxan toxicity, and which failed to inhibit streptolysin $O$, contained relatively high concentrations of phospholipid. The cholesterol/phospholipid ratio of these sera was considerably below 1.0. Similarly, the sera of animals which received Triton WR 1339 had relatively high concentrations of phospholipid and inhibited streptolysin $\mathrm{O}$ only at high serum dilutions. Thus, the inhibition of streptolysin $O$ by rabbit sera appeared to be related in a general way to the ratio of cholesterol to phospholipid (Figure 3).

The inhibition of saponin by hyperlipemic rabbit sera: Sera obtained in the experiments described above were also tested for inhibition of saponin to determine whether this hemolysin, which is also inhibited by cholesterol, was affected in the same fashion as streptolysin O. Several differences were noted. Inhibition of saponin hemolysis by the sera of cholesterol-fed rabbits was roughly proportionate to serum cholesterol concentration. In contrast to the findings with streptolysin $\mathrm{O}$ inhibition, intravenous injection of heparin failed to enhance the inhibition of hemolysis by saponin. In addition, the sera of alloxantoxic animals, and of Triton-treated animals, showed even'higher degrees of inhibition than that of cholesterol-fed rabbits at corresponding concentrations of serum cholesterol. In contrast to streptolysin $O$ inhibition, therefore, sera with proportionately higher concentrations of phospholipids were associated with enhancement of in- 
TABLE III

Non-specific inhibition of streptolysin $O$ by human hyperlipemic sera

\begin{tabular}{|c|c|c|c|c|c|c|c|c|c|c|c|}
\hline \multirow[b]{2}{*}{ Diagnosis } & \multirow{2}{*}{$\begin{array}{c}\text { No. of } \\
\text { Patients }\end{array}$} & \multicolumn{2}{|c|}{ Cholesterol, mg. \% } & \multicolumn{2}{|c|}{ Phospholipid, mg. \% } & \multicolumn{2}{|c|}{$\mathrm{C} / \mathrm{P}$ ratio } & \multicolumn{2}{|c|}{ SOI, $* u / c c$. } & \multicolumn{2}{|c|}{ Sap. inhib., $u / c c$} \\
\hline & & Range & Av. & Range & Av. & Range & Av. & Range & Median & Range & Av. \\
\hline $\begin{array}{l}\text { Obstructive } \\
\text { jaundice } \\
\text { Nephrosis } \\
\text { Familial hyper- }\end{array}$ & $\begin{array}{l}20 \\
17\end{array}$ & $\begin{array}{c}86-495 \\
306-1060\end{array}$ & $\begin{array}{l}256 . \\
554\end{array}$ & $\begin{array}{l}159-1215 \\
326-888\end{array}$ & $\begin{array}{l}461 . \\
554\end{array}$ & $\begin{array}{l}0.42-0.93 \\
0.72-1.25\end{array}$ & $\begin{array}{l}0.71 \\
1.02\end{array}$ & $\begin{array}{r}160-<20 \\
+640-<10\end{array}$ & $\begin{array}{l}<20 \\
<10\end{array}$ & $\begin{array}{l}10-33 \\
20-100\end{array}$ & $\begin{array}{l}18 . \\
54 .\end{array}$ \\
\hline $\begin{array}{l}\text { cholesterolemia } \\
\text { Diabetes } \\
\text { Coronary }\end{array}$ & $\begin{array}{l}5 \\
2\end{array}$ & $\begin{array}{l}208-468 \\
292-300\end{array}$ & $\begin{array}{l}355 \\
296\end{array}$ & $\begin{array}{l}260-676 \\
380-400\end{array}$ & $\begin{array}{l}407 . \\
390\end{array}$ & $\begin{array}{l}0.48-1.25 \\
0.75-0.77\end{array}$ & $\begin{array}{l}0.93 \\
0.76\end{array}$ & $\begin{array}{c}\dagger 640-40 \\
20-<20\end{array}$ & $\begin{array}{l}40 \\
20\end{array}$ & & \\
\hline $\begin{array}{l}\text { occlusion } \\
\text { Hepatitis } \\
\text { Myxedema }\end{array}$ & $\begin{array}{l}3 \\
9 \\
1\end{array}$ & $\begin{array}{l}200-356 \\
146-254\end{array}$ & $\begin{array}{l}265 \\
185 \\
418\end{array}$ & $\begin{array}{l}238-319 \\
189-572\end{array}$ & $\begin{array}{l}278 . \\
319 . \\
345\end{array}$ & $\begin{array}{l}0.84-1.12 \\
0.41-0.80\end{array}$ & $\begin{array}{l}0.98 \\
0.62 \\
1.21\end{array}$ & $\begin{array}{c}20-10 \\
160-<20\end{array}$ & $\begin{array}{l}10 \\
40 \\
40\end{array}$ & & \\
\hline
\end{tabular}

* SOI determinations were performed after absorption of specific antibody with streptolysin $\mathrm{O}$.

$\dagger$ The serum of one patient in this group had an SOI titer of 640 and a C/P ratio of 1.25 .

hibitory activity against saponin (Figure 4). There was no tendency of the sera of Triton-treated rabbits to show "prozoning" reactions with saponin.

\section{Hemolysin inhibition by human hypercholestero- lemic sera}

The sera of patients with a variety of diseases associated with hypercholesterolemia were studied for inhibition of hemolysis by streptolysin $\mathrm{O}$ and saponin. Sera with SOI titers of more than 160 units per ml. were absorbed with streptolysin $\mathrm{O}$ to remove specific antibody. Of 57 patients studied, the sera of only two showed significant streptolysin O inhibition (640 units) after specific antibody had been absorbed. One of these two patients manifested the nephrotic syndrome and the other had familial hypercholesterolemia. The ratio of cholesterol/phospholipid in both sera was 1.25, the highest observed in this series (Table III).

With the single exception mentioned above, sera from patients with the nephrotic syndrome showed the characteristic extremely low antistreptolysin $O$ titers that have been previously described $(22,23)$, and which have been explained in part by loss of specific antibody in the urine (24). Despite the very high values for serum cholesterol encountered in this group of patients, non-specific streptolysin $\mathrm{O}$ inhibition was observed in only one of the 17 patients studied.

Because the above data suggest that non-specific streptolysin $O$ inhibition is apparent only in sera in which the concentration of cholesterol significantly exceeds that of phospholipids, an attempt was made to determine whether enzymatic degradation of serum phospholipid would result in enhanced streptolysin $O$ inhibition. The sera of 15 patients with the nephrotic syndrome, and of 15 patients with hypercholesterolemic disorders, were assayed for streptolysin $O$ inhibition before and after digestion with lecithinase (purified alpha toxin of Clostridium welchii). Nine of the 15 sera of patients with nephrosis and 7 of the 15 sera of patients with other hypercholesterolemic syndromes, showed striking increase in streptolysin $O$ inhibition following lecithinase digestion. Treatment of these sera with lecithinase resulted in all instances in loss of over 90 per cent of phospholipid.

Total cholesterol content before and after lecithinase digestion remained virtually unaffected.

TABLE IV

Effect of lecithinase treatment upon streptolysin $O$ inhibition of human hyperlipemic sera

\begin{tabular}{|c|c|c|c|c|c|c|c|}
\hline \multirow[b]{2}{*}{ Patient } & \multirow[b]{2}{*}{ Disease } & \multicolumn{2}{|c|}{ SOI, $u / c c$. } & \multicolumn{2}{|c|}{ Phospholipid, mg. \% } & \multicolumn{2}{|c|}{ Cholesterol, mg. \% } \\
\hline & & Control & $\begin{array}{c}\text { Lecithinase } \\
\text { treated }\end{array}$ & Control & $\begin{array}{c}\text { Lecithinase } \\
\text { treated }\end{array}$ & Control & $\begin{array}{c}\text { Lecithinase } \\
\text { treated }\end{array}$ \\
\hline $\begin{array}{l}\text { SIM } \\
\text { MEN } \\
\text { YOR } \\
\text { KROP }\end{array}$ & $\begin{array}{l}\text { Nephrosis } \\
\text { Nephrosis } \\
\text { Ca of liver } \\
\text { Xanthomatosis }\end{array}$ & $\begin{array}{r}<10 \\
<10 \\
80 \\
40\end{array}$ & $\begin{array}{r}2,560 \\
20 \\
10,240 \\
80\end{array}$ & $\begin{array}{r}694 \\
562 \\
1,132 \\
406\end{array}$ & $\begin{array}{l}48 \\
41 \\
64 \\
30\end{array}$ & $\begin{array}{l}685 \\
604 \\
454 \\
401\end{array}$ & $\begin{array}{l}640 \\
590 \\
459 \\
384\end{array}$ \\
\hline
\end{tabular}




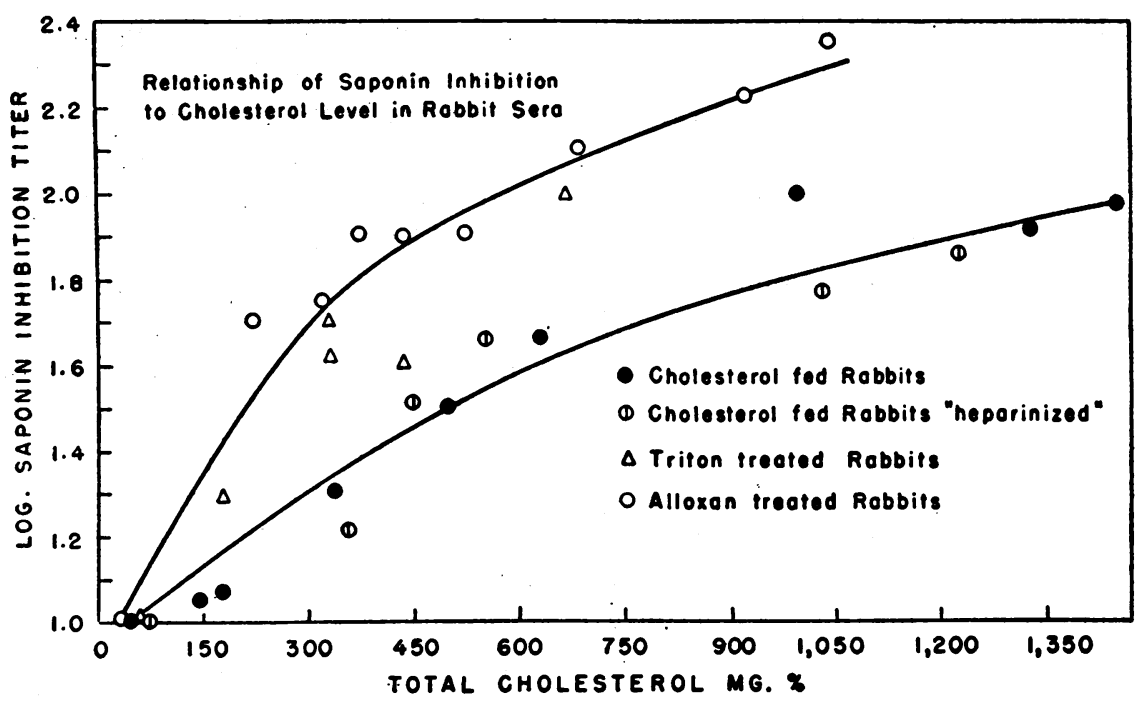

Fig. 4. Relationship of Saponin Inhibition to Cholesterol Level in Rabit Sera

The failure of some sera to develop increased inhibition of streptolysin $\mathrm{O}$ was, therefore, not due to either failure of the enzyme to disrupt phospholipid or to destruction of cholesterol (Table IV).

The inhibition of saponin by human hypercholesterolemic sera paralleled, in general, the concentration of serum cholesterol as has been previously observed (9). At normal concentrations of serum cholesterol, saponin inhibition titers ranged from 10 to 16 units. At serum cholesterol levels of $1,000 \mathrm{mg}$. per cent, saponin inhibition titers were approximately 100 units. It appears that in human, as in rabbit, serum the lipoprotein inhibition of saponin is quite distinct from that of streptolysin $\mathrm{O}$ inhibition.

The administration of heparin intravenously in doses of $100 \mathrm{mg}$. to one patient with hypercholesterolemia due to the nephrotic syndrome and to two patients who suffered recent coronary occlusion and who had high normal values of cholesterol in their sera, failed to produce significant increase in SOI titers. Alimentary hyperlipemia was not associated with increased SOI, even following the "clearing" effect produced by injection of heparin.

Because of reports that the sera of some patients with infectious hepatitis demonstrate marked non-specific streptolysin inhibition $(25,26), 17$ sera of six patients with infectious hepatitis " were

- These sera were kindly supplied by Dr. Roderick Murray of the National Microbiological Institute, $\mathrm{Na-}$ tional Institutes of Health. assayed for SOI from serial bleedings made during the course of their illness. None of the sera studied showed significant elevation of SOI titer.

\section{DISCUSSION}

One of the objectives of this study was to determine whether various types of hyperlipemic sera could be characterized by their capacity to inhibit the hemolysins employed. Marked inhibition of streptolysin $O$ hemolysis is characteristic of the sera of rabbits fed cholesterol and appears to be related to the high ratio of cholesterol to phospholipid in such sera. The "prozone" type of inhibition of streptolysin $\mathrm{O}$ by the sera of rabbits injected with Triton WR 1339 is also peculiar to these sera for reasons which are not explained. Human hypercholesterolemic sera do not inhibit streptolysin $O$ hemolysis non-specifically, except in rare instances when the ratio of cholesterol to phospholipid is unusually high. No characteristic pattern of hemolysin inhibition was observed, therefore, by which one clinical type of hyperlipemia could be distinguished from another. In this respect the inhibition of streptolysin $O$ by human sera appears to have limited clinical application.

The capacity of serum cholesterol to inhibit streptolysin $\mathrm{O}$ hemolysis may be of some interest, however, as a reflection of the structure and composition of serum lipoproteins. Serum cholesterol is considered to be combined with phospholipids in large lipoprotein complexes of varying size 
$(27,28)$. The configuration of cholesterol within such molecules apparently determines the availability of certain chemical groups to inhibit various hemolysins. The same serum may inhibit saponin hemolysis strongly but may not inhibit streptoly$\sin \mathrm{O}$ hemolysis at all. Cholesterol inhibits the hemolytic action of saponins by combining with them to form double compounds (3). Apparently streptolysin $\mathrm{O}$ is inhibited in an entirely different fashion.

The possibility was considered that phospholipid is combined with cholesterol in such a manner as to make it unavailable as an inhibitor of streptolysin O. This possibility prompted experiments employing a lecithinase to "liberate" cholesterol. Although most sera treated with lecithinase showed the expected increase in inhibition of streptolysin $O$ hemolysis, the results were not consistent.

The action of $\mathrm{Cl}$. welchii lecithinase upon human serum has been shown to affect profoundly the physical properties of serum beta-1 lipoprotein in studies employing ultracentrifugation and electrophoresis (29). The unstabilizing effect on serum lipids which is produced by the action of lecithinase (30) probably results in highly complex changes which cannot be interpreted simply as selective destruction of phospholipid. More likely such destruction results in the complete disruption of lipoprotein complexes. For example, when normal human serum which has been treated with $\mathrm{Cl}$. welchii lecithinase is subjected to ultracentrifugation by the sedimentation-flotation method of Gofman and his associates (28), practically no beta-1 lipoprotein can be recovered. Also, the clear beta lipoprotein solution obtained from human serum by this method (28) becomes intensely milky when treated with lecithinase and loses its normal property of streptolysin S inhibition (31). The alterations in serum lipoproteins produced by the action of lecithinase is reflected variously by the inhibition of three different hemolysins: an increase in streptolysin $\mathrm{O}$ inhibition, no change in saponin inhibition, and a decrease in streptolysin $\mathrm{S}$ inhibition (31). The effect of $\mathrm{Cl}$. welchii lecithinase upon rabbit sera could not be studied because this enzyme, for reasons not understood, does not react with animal sera (32).

The inhibition of streptolysin $\mathrm{O}$ hemolysis does not appear to depend entirely upon the ratio of cholesterol to phospholipid in serum. The en- hancing effect of heparin upon the inhibition of streptolysin $O$ by the sera of cholesterol-fed rabbits occurs in the absence of a significant change in this ratio. This effect of heparin may be related to the change in the size of lipoprotein molecules which occurs following injection of this substance $(19,33,34)$. In addition, the diluted sera of rabbits who received Triton WR 1339 intravenously showed inhibition of streptolysin $\mathrm{O}$ hemolysis even though the cholesterol/phospholipid ratio of such sera was quite low.

It is apparent that the inhibition of streptolysin $O$ hemolysis by serum lipids is a highly complex and as yet poorly understood phenomenon. The sensitivity of this hemolytic system to variations in the physicochemical state of serum lipoproteins does, however, afford an opportunity for empirical observations of the behavior of these lipoproteins in intact serum.

\section{SUMMARY}

Various types of hyperlipemic rabbit and human sera were tested as inhibitors of two hemolysins, streptolysin $O$ and saponin, both of which are known to be inhibited by cholesterol. Certain types of sera showed distinctive properties as inhibitors of these hemolysins.

Streptolysin $\mathrm{O}$ hemolysis was strongly inhibited by the sera of rabbits fed cholesterol. This inhibition was enhanced by the administration of heparin to these animals. Inhibition of streptolysin $O$ hemolysis appeared to be related to a high ratio of the concentration of serum cholesterol to serum phospholipids.

Human hypercholesterolemic sera did not inhibit streptolysin $\mathrm{O}$ except in rare instances where the ratio of serum cholesterol to phospholipid was unusually high. Enzymatic degradation of phospholipids by $\mathrm{Cl}$. welchii lecithinase resulted, in most instances, in marked increase in the inhibition of streptolysin $\mathrm{O}$ hemolysis.

The inhibition of saponin hemolysis was quite different from that of streptolysin $O$. The inhibition of saponin appeared to be related in general to absolute cholesterol concentration rather than to cholesterol/phospholipid ratios.

The property of streptolysin $O$ inhibition by sera appears to be closely related to the chemical structure and physical state of serum lipoproteins. 


\section{ACKNOWLEDGMENT}

The author is indebted to Dr. Colin M. MacLeod for his advice and suggestions during these studies.

\section{REFERENCES}

1. Todd, E. W., The differentiation of two distinct serological varieties of streptolysin, streptolysin $O$ and streptolysin S. J. Path. \& Bact., 1938, 47, 423.

2. Hewitt, L. F., and Todd, E. W., The effect of cholesterol and of sera contaminated with bacteria on the haemolysins produced by haemolytic streptococci. J. Path. \& Bact., 1939, 49, 45.

3. Van Heyningen, W. E., Bacterial Toxins, Springfield, IIl., Charles C Thomas, 1950.

4. Stollerman, G. H., Bernheimer, A. W., and MacLeod, C. M., The association of lipoproteins with the inhibition of streptolysin S by serum. J. Clin. Invest., $1950,29,1636$.

5. Stollerman, G. H., Brodie, B. B., and Steele, J. M., The relationship of streptolysin $S$ inhibitor to phospholipids in the serum of human beings and experimental animals. J. Clin. Invest., 1952, 31, 180.

6. Stollerman, G. H., and Bernheimer, A. W., Inhibition of streptolysin $S$ by the serum of patients with rheumatic fever and acute streptococcal pharyngitis. J. Clin. Invest., 1950, 29, 1147.

7. Humphrey, J. H., The nature of antistreptolysin " $S$ " in the sera of man and of other species: Antistreptolysin titres in normal and diseased states. Brit. J. Exper. Path., 1949, 30, 345.

8. Humphrey, J. H., The nature of antistreptolysin $\mathrm{S}$ in the sera of man and of other species. The lipoprotein properties of antistreptolysin S. Brit. J. Exper. Path., 1949, 30, 365.

9. Ponder, E., Hemolysis and Related Phenomena, New York, Grune and Stratton, 1948, p. 270.

10. Todd, E. W., Antigenic streptococcal hemolysin. J. Exper. Med., 1932, 55, 267.

11. Rantz, L. A., and Randall, E., A modification of the technic for determination of the antistreptolysin titer. Proc. Soc. Exper. Biol. \& Med., 1945, 52, 22.

12. Schoenheimer, R., and Sperry, W. M., A micromethod for the determination of free and combined cholesterol. J. Biol. Chem., 1934, 106, 745.

13. Sperry, W. M., and Webb, M., A revision of the Schoenheimer-Sperry method for cholesterol determination. J. Biol. Chem., 1950, 187, 97.

14. Zilversmit, D. B., and Davis, A. K., Microdetermination of plasma phospholipids by trichloroacetic acid precipitation. J. Lab. \& Clin. Med., 1950, 35, 155.

15. MacLeod, C. M., and Avery, O. T., The occurrence during acute infections of a protein not normally present in the blood. II. Isolation and properties of the reactive protein. J. Exper. Med., 1941, 73, 183.

16. Adams, M. H., and Hendee, E. D., Methods for the production of the alpha and theta toxins of Clostridium welchii. J. Immunol., 1945, 51, 249.

17. Kellner, A., Correll, J. W., and Ladd, A. T., Sustained hyperlipemia induced in rabbits by means of intravenously injected surface-active agents. J. Exper. Med, 1951, 93, 373.

18. Pierce, F. T., Jr., The relationship of serum lipoproteins to atherosclerosis in the cholesterol-fed alloxanized rabbit. Circulation, 1952, 5, 401.

19. Graham, D. M., Lyon, T. P., Gofman, J. W., Jones, H. B., Yankley, A., and Simonton, J., Blood lipids and human atherosclerosis. II. The influence of heparin upon lipoprotein metabolism. Circulation, 1951, 4, 666.

20. Kendall, F. E., Meyer, W., Lewis, L., and Victor, J., Alloxan diabetes in rabbits. Production of hypercholesterolemia, hyperlipemia and adrenal cortical lesions. Proc. Soc. Exper. Biol. \& Med., 1945, 60, 190.

21. Payne, T. P. B., and Duff, G. L., Serum lipids and their fractionation in alloxan diabetes in the rabbit. Proc. Soc. Exper. Biol. \& Med., 1950, 73, 332.

22. Lyttle, J. D., Seegal, D., Loeb, E. N., and Jost, E. L., The serum antistreptolysin titer in acute glomerulonephritis. J. Clin. Invest., 1938, 17, 631.

23. Rantz, L. A., DiCaprio, J., and Randall, E., Antistreptolysin $\mathrm{O}$ and antihyaluronidase titers in health and in various diseases. Am. J. Med. Sc., 1952, n.s. 224, 194.

24. Rytand, D. A., Rantz, L. A., and Randall, E., Antistreptolysin " $O$ " in urine and serum of patients with the nephrotic syndrome. J. Clin. Invest., 1950, 29, 843.

25. Packalén, T., Nonspecific antistreptolysin reactions and serum (or pleural-exudate) cholesterol. J. Bact., 1948, 56, 143.

26. Oker-Blom, N., Nikkilä, E., and Kalaja, T., Nonspecific antistreptolysin reactions in hepatitis sera, antistreptolysin titers before and after removal of lipids from the hepatitis sera with bentonite. Ann. med. exper. et biol. Fenniae, 1950, 28, 125.

27. Oncley, J. L., Gurd, F. R. N., and Melin, M., Preparation and properties of serum and plasma proteins. $\mathrm{XXV}$. Composition and properties of human serum $\beta$-lipoprotein. J. Am. Chem. Soc., 1950, 72, 458.

28. Gofman, J. W., Jones, H. B., Lindgren, F. T., Lyon, T. P., Elliott, H. A., and Strisower, B., Blood lipids and human atherosclerosis. Circulation, 1950, 2,161 .

29. Petermann, M. L., Effect of lecithinase on human serum globulins. J. Biol. Chem., 1946, 162, 37.

30. Ahrens, E. H., Jr., and Kunkel, H. G., The stabilization of serum lipid emulsions by serum phospholipids. J. Exper. Med., 1949, 90, 409.

31. Stollerman, G. H., and Petermann, M. L., Unpublished observations.

32. Nagler, F. P. O., Observations on a reaction between the lethal toxin of $\mathrm{Cl}$. welchii (type A) and human serum. Brit. J. Exper. Path., 1939, 20, 473.

33. Hahn, P. F., Abolishment of alimentary lipemia following injection of heparin. Science, 1943, 98, 19.

34. Anfinsen, C. B., Boyle, E., and Brown, R. K., The role of heparin in lipoprotein metabolism. Science, 1952, 115, 583. 